\title{
ОСНОВНІ КОМПОНЕНТИ СОЦІАЛЬНОЇ КОМПЕТЕНТНОСТІ СІМЕЙНИХ ЛІКАРІВ В УКРАЇНІ
}

\author{
L. V. Lymar \\ O. Bohomolets National Medical University, Kyiv

\section{BASIC COMPONENTS OF FAMILY DOCTORS’ SOCIAL COMPETENCE IN UKRAINE}

\begin{abstract}
Анотація. Робота присвячена відносно новому в системі охорони здоров’я України поняттю соціальної компетентності сімейних лікарів.

Соціальна компетентність сімейного лікаря є різновидом його професійної компетентності та становить сукупність знань, умінь та навичок взаємодії у медичному середовищі при здійсненні професійної діяльності. Соціальний характер роботи сімейного лікаря обумовлює необхідність розвитку його соціальної компетентності. В межах соціальної компетентності сімейного лікаря, який активно взаємодіє з іншим медичним персоналом, пацієнтами та їх родичами, виділено такі компоненти: мотиваційно-вольовий, організаційно-діяльнісний та когнітивний. Мотиваційно-вольовий компонент представлений мотивами сімейного лікаря до взаємодії з пацієнтом (які, у свою чергу, обумовлені мотивами вибору спеціалізації) та емоційно-вольовими характеристиками лікаря (навички самоспостереження, самокорекції тощо). Когнітивний компонент представлений системою сформованих знань про способи взаємодії з пацієнтами, норми соціальної взаємодії та стандарти деонтології. Організаційнодіяльнісний компонент представлений тим, як саме лікар втілює свої знання на практиці, який стиль взаємодії обирає, які стратегії спілкування тощо. Перспективне дослідження рівня сформованості компонентів у студентів - майбутніх сімейних лікарів та практикуючих фахівців.

Соціальна компетентність $є$ необхідним компонентом професійної компетентності сімейного лікаря. Корекція визначених трьох компонентів соціальної компетентності сімейного лікаря окремо та в цілому як єдиної структурної системи сприятиме покращенню сумарної соціальної компетентності сімейного лікаря, відтак якості взаємодії з пацієнтами та продуктивності роботи.
\end{abstract}

Ключові слова: соціальна компетентність; сімейний лікар; взаємодія; пацієнт; компонент.

Abstract. The article is dedicated to relatively new in the Ukrainian Healthcare notion of the family doctors' social competence.

Social competence of a family doctor is a type of his professional competence, represented with his knowledge, skills and abilities of interaction within the medical environment when performing the professional duties, interacting with the medical personnel, patients and their relatives. Social character of the family doctor's profession predisposes for necessity of his social competence development. Within the family doctor's social competence structure, the following components have been established: motivation, management and cognition. The motivation component is represented with the doctor's motivation for work as well as numerous traits of his character which characterize his personality (will component, ability to restrain oneself). The cognition component is represented with the knowledge and abilities of productive communication and skills of their practical application. The management component includes interaction and conflict management strategies (communication mindset, tolerance, etc.). Testing social competence level both in future family doctors (medical students) and already practicing specialists should be implemented. Social competence represents a necessary component of the family doctor professional competence. The correction of these defined components of the family doctor's social competence separately and as a whole structure will provide for improvement of the family doctor performance and quality of his work.

Key words: social competence; family doctor; interaction; patient; component.

Вступ. Європейський курс України передбачає необхідність реформування всіх галузей, зокрема системи охорони здоров'я, з метою покращення якості надання послуг пацієнтам та конкурентоспроможності вітчизняних лікарів за кордоном. Останнє можливо за умови набуття ними висо-

(c) Л. В. Лимар кого рівня професійної компетентності. Одним із підвидів професійної компетентності є соціальна компетентність, розвиток якої обумовлює здатність лікаря високоефективно взаємодіяти у медичному середовищі з іншими лікарями, керівництвом, пацієнтами та їх рідними, а також у межах всієї системи охорони здоров'я, що особливо стосу- 
ється сімейних лікарів, які за фахом взаємодіють 3 великою кількістю людей. 3 метою покращення розуміння та деталізації поняття соціальної компетентності лікарів, зокрема сімейних, та подальшої iї корекції, нами було обрано тему дослідження: основні компоненти соціальної компетентності сімейних лікарів.

Мета статті - на основі проведеного аналізу літературних джерел визначення поняття «соціальна компетентність сімейних лікарів», а також її основних структурних компонентів, з подальшою перспективою корекції.

Теоретична частина. Дослідження поняття соціальної компетентності в межах професійної (а також соціально-комунікативної, чи комунікативної як підтипу соціальної) набуло в Україні поширення, починаючи з 2008 р. Дослідження соціальної компетентності в рамках компетентнісного підходу до оцінювання професіоналізму фахівців, зокрема медиків, відображено в численних роботах зарубіжних науковців: D. Guerrero (дослідження професійних компетентностей та визначення основних їх моделей) [9], W. R. Dunn (визначення ключових компетентностей у лікарів та їх корекція) [8], T. W. Koenig (ключові особистісні компетенції абітурієнтів та студентів-медиків) [12], N. Bryl (вплив ступеня розвитку соціальної компетентності лікаря на результат лікування пацієнтів 3 остеопорозом) [6], M. K. Buller (стиль комунікації як складова соціальної компетентності лікарів та якість взаємодії з пацієнтами) [7], C. Loignon (соціальна компетентність лікарів та їх взаємодія з пацієнтами з бідних та неблагонадійних районів) [13], J. O. Reimann (соціокультурна компетентність лікарів, які працюють із мексиканським населенням) [16], C. Kiessling (навчання соціальних компетентностей протягом навчання студентів-медиків у Німеччині) [10], G. Kinman (соціальна компетентність соціальних працівників) [11], J. K. Stoller (емоційний інтелект лікарів та споріднена 3 ним соціальна компетентність) [17].

Власне термін «компетентність» було запроваджено в 1959 p. R. White як здатність особи до взаємодії [18]. Щодо соціальної компетентності взагалі С. Краснокутська [3] визначає її як здатність та готовність особистості до взаємодії з суспільством, на рівні пари (з іншою особою), в малій групі, в колективі чи на рівні загальної системи. Згідно з Matczak, соціальна компетентність дозволяє особі ефективно діяти у певних ситуаціях, разом з іншими особами [15]. А. Ковальова у своїх досліджен- нях взагалі поєднує соціальну та комунікативну компетентності [2]. Проведений аналіз показує, що в контексті медичної професії можливо соціальну компетентність охарактеризувати як набір знань, умінь та навичок ефективної взаємодії лікаря з пацієнтами, родичами пацієнтів, колегами, керівництвом та усією системою охорони здоров'я (міжвідомча комунікація, наприклад), проте найбільший інтерес у сучасних дослідженнях викликає саме соціальна компетентність лікаря при його взаємодії з пацієнтами.

Посадова інструкція сімейного лікаря [5] обумовлює, що лікар, керуючись чинним законодавством України, надає кваліфіковану медичну допомогу окремій особі та його родині. Тобто спеціалізація сімейного лікаря є високо соціально спрямованою. Отже, соціальну компетентність сімейного лікаря можливо визначити як набір знань, вмінь та навичок про способи взаємодії з пацієнтом та його родиною, а також взаємодію з іншими фахівцями в межах роботи з певним пацієнтом чи його родиною. Власне, це підготовленість сімейного лікаря до спілкування з оточуючими в межах ситуації лікування пацієнта чи його родини, згідно 3 законодавством країни та визначеними деонтологічними та етичними, а також загальними суспільними правилами, проте у лікарській професії на першому місці постають деонтологічні цінності, а потім - загально-суспільно-етичні. Так, уникання пацієнта чи повідомлення неправдивої інформації з соціального погляду є негативним явищем, коли ж неповідомлення пацієнту про термінальний діагноз на пізній стадії онкологічного захворювання може бути деонтологічно схваленим рішенням.

Ми адаптували загальну структуру I. Кобилянської [1], щодо соціальної компетентності сімейного лікаря, і виділили такі компоненти:

1. Особистісний: «я-концепція» особистості, тобто те, наскільки лікар усвідомлює власні бажання, мотиви, яким він хоче бути; емоції та відчуття лікаря й усвідомлення їх, тип темпераменту, інтра- чи екстравертованість особи; домінуючий тип мислення; швидкість реакції, навички самомоніторингу та саморегуляції, причому останні відіграють важливе значення, особливо при взаємодії з іншими. 2. Знання основних норм, стандартів взаємодії в суспільстві та стандартів взаємодії в межах системи «лікар - суспільство» (соціальні норми й деонтологічні стандарти професійної поведінки взагалі та поведінки безвідносно до професії), тобто лікар має знати соціально-теоретичну базу взаємодії з па- 
цієнтами. 3. Вміння та навички взаємодії з іншими в межах медичного середовища, зокрема з пацієнтами та їх ефективне практичне застосування, незалежно від його соціального статусу, статі, гендерної самоідентифікації, а також національності. Варто зазначити, що обізнаність лікаря зі стандартами взаємодії не гарантує їх застосування на практиці. Проте ми вважаємо за більш доцільне проаналізувати структуру соціальної компетентності сімейного лікаря [4], виокремивши наступні компоненти: мотиваційно-вольовий, організаційно-діяльнісний та когнітивний.

Мотиваційно-вольовий компонент соціальної компетентності сімейного лікаря включає в собі мотивацію до взаємодії та емоційно-вольові якості лікаря. Власне мотивація до взаємодії може бути обумовлена мотивацією професійної діяльності та мотивацією вибору професії фахівцем. Мотивація вибору професії здебільшого обумовлює мотивацію професійної діяльності, проте інколи ці фактори є різними. Так, мотивація вибору професії сімейного лікаря може бути внутрішньою (власне усвідомлене бажання лікаря працювати саме за даною спеціалізацією) та зовнішньою (поради друзів, батьків, сімейна традиція, або обставини, або ж вимушений вибір професії через держзамовлення та необхідність набору на вакантні місця). Спеціалізація сімейного лікаря обумовлює велику відповідальність, необхідність знання комплексу медичних дисциплін, а не вузькоспеціалізованої галузі, окрім того, пов'язана з більш ймовірним працевлаштуванням у державну, а не приватну структуру. Мотивація вибору професії закладається при вступі, розвивається при навчанні у ВНЗ та по його закінченні плавно трансформується у мотивацію професійної діяльності та фахової взаємодії [14]. Ось чому важливо визначати мотивацію вибору професії на етапі вступу та навчання студентів на молодших курсах з метою її корекції.

У 2018-2019 н. р. було проведене опитування студентів-першокурсників НМУ ім. О. О. Богомольця щодо мотивації вибору професії та можливого подальшого фаху. Студентам було запропоновано відповісти на ряд питань, серед яких були: «Чи хочете Ви у майбутньому стати сімейним лікарем», а також «Виберіть зі списку запропонованих спеціалізацій ту, за якою хочете працювати у майбутньому». Всього було опитано 140 студентів 1 курсів, з яких 69 \% дали негативну відповідь на запитання про ймовірне обрання спеціалізації сімейного лікаря у майбутньому, а з-поміж запропонованих спеціалізацій найчастіше обирали «хірург» - 54 \%, «гінеколог» - 31 \%, «офтальмолог» - 4 \% та «ендокринолог» - 3,5 \%. Отримані дані вказують на відсутність мотивації вибору спеціалізації сімейного лікаря студентами-першокурсниками. На нашу думку, це пояснюється високими вимогами до спеціальності, високим навантаженням та обов’язками сімейного лікаря, а також створеним іміджем низької зарплати сімейного лікаря, і в даному випадку необхідно підняти імідж професії сімейного лікаря в мас-медіа на рівні міністерства, а також проводити просвітницьку роботу з випускниками.

Мотивація вибору професії обумовлює мотивацію професійної діяльності, а отже, і соціальну мотивацію сімейного лікаря, серед підвидів якої можливо виділити підгрупи:

- прагматично-матеріальна мотивація, у даному випадку рівень соціальної компетентності сімейного лікаря низький, причому якщо лікар вмотивований працювати просто «за зарплату», можливо говорити про відсутність інтересу до професії, коли ж матеріальна мотивація стосується додаткової «подяки» від пацієнтів, спостерігаємо відсутність мотивації лікаря до кінцевого результату - одужання пацієнта;

- соціальна: самоствердження «я-лікар», повага в родині чи суспільстві, спілкування 3 людьми 3 позиції лікаря. Варто зазначити, що авторитет лікарської професії наразі підірваний, стереотип про «клятву Гіппократа» та необхідність лікувати пацієнтів також не сприяє поширенню мотивації до фаху. Вважаємо, що інформаційно-освітня кампанія на рівні держави з метою виховання поваги до спеціалізації могла би змінити цей стан;

- альтруїстична мотивація: робота заради інших, сенс роботи - лікування, і як наслідок, взаємодія 3 пацієнтами. Лікар зацікавлений в одужанні пацієнтів, соціальна компетентність лікаря представлена найвище.

Вольова складова мотиваційно-вольового компонента соціальної компетентності сімейного лікаря представлена вміннями емоційного самомоніторингу та саморегуляції в умовах взаємодії 3 пацієнтами, зокрема в умовах перепрацювання, роботи з великою кількістю пацієнтів, та емоційного вигорання.

За умови високого рівня самомоніторингу та саморегуляції (лікар усвідомлює власні почуття, що його бентежить чи дратує, вміє вчасно зупинити емоційний вияв, не виявляє свої емоції при пацієнтові, не кричить на пацієнтів), а також переважання 
альтруїстичної мотивації до взаємодії з пацієнтами визначаємо високий рівень розвитку компонента, за умови низького рівня самоконтролю, грубого поводження $з$ пацієнтами лікаря, а також коли взаємодію визначає прагматична мотивація, рівень розвитку компонента низький.

Когнітивний компонент соціальної компетентності сімейного лікаря представлений загальними знаннями з соціальної психології, а також знаннями основ соціальної взаємодії з пацієнтами, базовими деонтологічними та етико-правовими знаннями, які необхідно постійно обновляти. На жаль, швидкий темп роботи сімейного лікаря та постійна взаємодія з великою кількістю пацієнтів може не залишати час на соціальне навчання фахівця, чому варто приділяти увагу на рівні керівництва медичного закладу.

Організаційно-діяльнісний компонент соціальної компетентності сімейного лікаря представлений власне уміннями та навичками організації взаємодії з пацієнтами, стратегіями поведінки тощо. Так, приниження або залякування лікарем пацієнта (якщо не зробите аналізи сьогодні - завтра вам буде погано) є виявом низької соціальної компетентності, коли компроміс та адаптація лікаря 3 пацієнтом - високої. Також даний компонент охоплює стратегії взаємодії з пацієнтами, включаючи вербальне та невербальне спілкування. За своїми обов’язками сімейний лікар має спілкуватися 3 великою кількістю пацієнтів протягом дня. Стиль спілкування лікаря визначає довіру чи недовіру до нього пацієнтів, відтак заздалегідь сформована негативна комунікативна установка (зверхній, хамський стиль спілкування), буркотіння (постійна незадоволеність лікаря, обзивання пацієнтів) є показником низької соціальної компетентності. Крім психологічної складової, варто також зазначити, що даний компонент представлений уміннями лікаря грамотно спілкуватися з пацієнтами, державною мовою (і тут спостерігаємо протиріччя між правовою та соціальною компетентністю лікаря, коли за законом він має спілкуватися з російськомовними пацієнтами українською, проте з деонтологічних показників, якщо пацієнти не володіють українською і він має змогу перейти на російську, варто

\section{Список літератури}

1. Кобилянська I. М. Застосування ризик-орієнтованого підходу при формуванні у студентів компетенцій 3 безпеки життєдіяльності / I. М. Кобилянська, О. В. Кобилянський // Педагогічні науки: теорія, історія, інноваційні технології. - 2013. - № 7. - С. 109-119. так і робити), а також умінням чітко пояснювати доступною мовою, без перенавантаження термінологічним апаратом. Отже, високий рівень розвитку компонента можливо визначити при переважанні стратегії співпраці та пристосування при взаємодії з пацієнтами, коли ж конкуренція (приниження пацієнта) чи уникання (лікар намагається не взаємодіяти з неприємним йому пацієнтом) як стратегія взаємодії визначають низький рівень розвитку компонента.

Висновки та перспективи подальших досліджень. Отже, проведений аналіз літератури дав змогу визначити поняття соціальної компетентності сімейного лікаря як набір знань, вмінь та навичок про способи взаємодії з пацієнтом та його родиною, а також взаємодію з іншими фахівцями в межах роботи з певним пацієнтом чи його родиною. Власне, це підготовленість сімейного лікаря до спілкування з оточуючими в межах ситуації лікування пацієнта чи його родини, згідно з законодавством країни та визначеними деонтологічними та етичними, а також загальними суспільними правилами. В межах структури соціальної компетентності сімейного лікаря можливо виокремити такі компоненти: мотиваційно-вольовий, організаційно-діяльнісний та когнітивний. Мотиваційновольовий компонент представлений мотивами сімейного лікаря до взаємодії з пацієнтом (які, у свою чергу, обумовлені мотивами вибору спеціалізації) та емоційно-вольовими характеристиками лікаря (навички самоспостереження, самокорекції тощо). Когнітивний компонент представлений системою сформованих знань про способи взаємодії з пацієнтами, норми соціальної взаємодії та стандарти деонтології. Організаційно-діяльнісний компонент представлений тим, як саме лікар втілює свої знання на практиці, який стиль взаємодії обирає, які стратегії спілкування тощо. Вважаємо перспективним проведення емпіричного дослідження рівня сформованості мотиваційно-вольового та організаційно-діяльнісного компонентів у студентів - майбутніх сімейних лікарів та практикуючих сімейних лікарів, а також розробку та їх впровадження в навчально-виховний процес медичного ВНЗ.

2. Ковальова А. В. Відбір навчального матеріалу у формуванні іншомовної професійної компетенції / А. В. Ковальова // Вісник ХНУ / Викладання мов у вищих навчальних закладах освіти. - 2012. - № 21. С. $126-134$. 
3. Краснокутская С. Н. Формирование социальной компетентности студентов вуза : автореф. дисс. на соиск. уч. степ. канд. пед. наук / С. Н. Краснокутская. 2006. - 23 c.

4. Лимар Л. В. Аналіз дослідження сформованості готовності до безконфліктної взаємодії з пацієнтами студентів-медиків / Л. В. Лимар // Вісник Чернігівського нац. пед. ун-ту ім. Т. Г. Шевченка. Серія «Психологічні науки. - 2010. - Т. 82. - С. 366-371.

5. Посадова інструкція сімейного лікаря [Електронний ресурс]. - Режим доступу : https://www.medsprava.com. ua/article/1412-posadova-nstruktsya-smeynogo-lkarya.

6 . Bryl N. Influence of social competence of physicians on patient compliance with osteoporosis medications - a study on Polish postmenopausal women / N. Bryl // Ginekologia Polska. - 2012. - Vol. 83. - No. 7. - P. 511-517.

7. Buller M. K. Physicians’ communication style and patient satisfaction / M. K. Buller, D. B. Buller // Journal of Health and Social Behavior. - 1987. - P. 375-388.

8. Dunn W. R. Techniques of identifying competencies needed of doctors / W. R. Dunn, D. D. Hamilton, R. M. Harden // Medical Teacher. - 1985. - Vol. 7, No. 1. - P. 15-25.

9. Guerrero D. Professional competences: a classification of international models / D. Guerrero, I. De los Ríos // Procedia-Social and Behavioral Science Journal. - 2012. Vol. 46. - P. 1290-1296.

10. Kiessling C. Communication and social competencies in medical education in German-speaking countries: The Basel Consensus Statement: Results of a Delphi Survey / C. Kiessling // Patient Education and Counseling. - 2010. Vol. 81, No. 2. - P. 259-266.

\section{References}

1. Kobylianska, I.M., \& Kobylianskyi, O.V. (2013). Zastosuvannia ryzyk-oriientovanoho pidkhodu pry formuvanni u studentiv kompetentsii z bezpeky zhyttiediialnosti (Application of risk-oriented approach while forming the life safety competences in the students)]. Pedahohichni nauky: teoriia, istoriia, innovatsiini tekhnolohii - Pedagogical Sciences: Theory, History, Innovation Technologies, 7, 109-119 [in Ukrainian].

2. Kovalova, A.V. (2012). Vidbir navchalnoho materialu u formuvanni inshomovnoi profesiinoi kompetentsii [Choosing the training materials for shaping foreign-language professional competency]. Visnyk KhNU/ Vykladannia mov $u$ vyshchykh navchalnykh zakladakh osvity - Review of KNU/ Teaching languages in High Institutions, (21), 126-134 [in Ukrainian].

3. Krasnokutskaya, S.N. (2006). Formirovanye sotsyalnoy kompetentnosti studentov vuza [Shaping social competence in students]. Candidate's Extended abstract [in Russian].

4. Lymar, L.V. (2010). Analiz doslidzhennia sformovanosti hotovnosti do bezkonfliktnoi vzaiemodii z patsiientamy studentiv-medykiv (Analysis of assays on the readiness of medical students to conflictless interaction with patients].
11. Kinman G. Exploring stress resilience in trainee social workers: The role of emotional and social competencies / G. Kinman, L. Grant // The British Journal of Social Work. - 2010. - Vol. 41, No. 2. - P. 261-275.

12. Koenig T. W. Core personal competencies important to entering students' success in medical school: what are they and how could they be assessed early in the admission process? / T. W. Koenig // Academic Medicine. - 2013. Vol. 88, No. 5. - P. 603-613.

13. Loignon C. Physicians' social competence in the provision of care to persons living in poverty: research protocol / C. Loignon // BMC Health Services Research. - 2010. - Vol. 10, № 1. - P. 79-84.

14. Lymar L. Factors of the medical career choice within the context of ukrainian healthcare reforms / L. Lymar, S. Omelchuk // Wiadomosci Lekarskie (Warsaw, Poland: 1960). - 2018. - T. 71, №. 1 pt 2. - P. 211-216.

15. Matczak A. Kwestionariusz kompetencji społecznych / A. Matczak // Podręcznik. - 2nd ed. - Warszawa : Pracownia Testów Psychologicznych PTP, 2012. - 468 p.

16. Reimann J. O. F. Cultural competence among physicians treating Mexican Americans who have diabetes: A structural model / J. O. F. Reimann // Social Science \& Medicine. - 2004. - Vol. 59, No. 11. - P. 2195-2205.

17. Stoller J. K. Emotional intelligence competencies provide a developmental curriculum for medical training / J. K. Stoller, C. A. Taylor, C. F. Farver // Medical Teacher. 2013. - Vol. 35, No. 3. - P. 243-247.

18. White R. W. Motivation reconsidered: The concept of competence / R. W. White // Psychological Review. - 1959. - Vol. 66 (5). - P. 297-333. - Access mode : http://dx.doi. org/10.1037/h0040934.

Visnyk Chernihivskoho nats. ped. Un-tu im. T.H. Shevchenka. Seriia Psykholohichni nauky - Herald of Chernivtsi National Pedagogical University named after T.H. Shevchenko, Psychological Sciences, 82, 366-371 [in Ukrainian].

5. Posadova instruktsiia simeinoho likaria [Positional instruction of family doctor]. Retrieved from: https://www. medsprava.com.ua/article/1412-posadova-nstruktsyasmeynogo-lkarya [In Ukrainian].

6. Bryl, N., Horst-Sikorska, W., Ignaszak-Szczepaniak, M., Marcinkowska, M., Michalak, M., \& Sewerynek, E. (2012). Influence of social competence of physicians on patient compliance with osteoporosis medications - a study on Polish postmenopausal women. Ginekologia Polska, 83 (7).

7. Buller, M.K., \& Buller, D.B. (1987). Physicians’ communication style and patient satisfaction. Journal of Health and Social Behavior, 375-388.

8. Dunn, W.R., Hamilton, D.D., \& Harden, R.M. (1985). Techniques of identifying competencies needed of doctors. Medical Teacher, 7 (1), 15-25.

9. Guerrero, D., \& De los Ríos, I. (2012). Professional competences: a classification of international models. ProcediaSocial and Behavioral Sciences, 46, 1290-1296. 
10. Kiessling, C., Dieterich, A., Fabry, G., Hölzer, H., Langewitz, W., Mühlinghaus, I., ... \& behalf of the Committee, O. (2010). Communication and social competencies in medical education in German-speaking countries: The Basel Consensus Statement.: Results of a Delphi Survey. Patient Education and Counseling, 81(2), 259-266.

11. Kinman, G., \& Grant, L. (2010). Exploring stress resilience in trainee social workers: The role of emotional and social competencies. The British Journal of Social Work, 41(2), 261-275.

12. Koenig, T.W., Parrish, S.K., Terregino, C.A., Williams, J.P., Dunleavy, D.M., \& Volsch, J.M. (2013). Core personal competencies important to entering students' success in medical school: what are they and how could they be assessed early in the admission process? Academic Medicine, 88 (5), 603-613.

13. Loignon, C., Haggerty, J.L., Fortin, M., Bedos, C.P., Allen, D., \& Barbeau, D. (2010). Physicians’ social competence in the provision of care to persons living in poverty: research protocol. BMC Health Services Research, 10 (1), 79.
14. Lymar, L., \& Omelchuk, S. (2018). Factors of the medical career choice within the context of ukrainian healthcare reforms. Wiadomosci lekarskie. Warsaw, Poland: 1960, 71 (1 pt 2), 211-216.

15. Matczak, A. (2001). Kwestionariusz Kompetencji SpoĹ ,ecznych: KKS: podrÄтм cznik. Pracownia Test $\breve{ł w ~ P s y c h o l o g i c z n y c h ~ P o l s k i e g o ~ T o w a r z y s t w a ~}$ Psychologicznego.

16. Reimann, J.O., Talavera, G.A., Salmon, M., Nuñez, J.A., \& Velasquez, R.J. (2004). Cultural competence among physicians treating Mexican Americans who have diabetes: A structural model. Social Science \& Medicine, 59 (11), 2195-2205.

17. Stoller, J.K., Taylor, C.A., \& Farver, C.F. (2013). Emotional intelligence competencies provide a developmental curriculum for medical training. Medical Teacher, 35 (3), 243-247.

18. White, R.W. (1959). Motivation reconsidered: The concept of competence. Psychological Review, 66 (5), 297.

Отримано 10.04.19

Рекомендовано 12.04.19

Електронна адреса для листування: lesyalymar@ukr.net 